ASTHMA

\title{
Association between leptin and asthma in adults
}

\author{
A Sood, E S Ford, C A Camargo Jr
}

Thorax 2006;61:300-305. doi: 10.1136/thx.2004.031468

See end of article for authors' affiliations

.....................

Correspondence to:

Dr A Sood, Southern

Illinois University School of

Medicine, Division of

Pulmonary and Critical

Care Medicine, 701 North

First Street, Room D434,

P O Box 19636,

Springfield,

IL 62794-9636, USA;

asood2@siumed.edu

Received 12 July 2004

Accepted 11 January 2006
Background: Leptin, a pro-inflammatory cytokine produced by adipose tissue, has previously been shown to be associated with asthma in children. We hypothesised that high serum leptin concentrations would also be associated with asthma in adults.

Methods: The Third National Health and Nutrition Examination Survey is a cross sectional study that included fasting serum leptin concentrations and self-report of doctor diagnosed asthma. Data were analysed using multivariable logistic regression analysis.

Results: Of 5876 participants, those with current asthma had a higher mean unadjusted leptin concentration than those who had never had asthma (geometric mean (SE) 9.2 (0.6) $\mu \mathrm{g} / \mathrm{l} v 7.6(0.2) \mu \mathrm{g} / \mathrm{l}$; $p=0.02$ ). After adjustment for triceps skinfold thickness and other covariates, the association between leptin and asthma appeared stronger in women than in men, and in premenopausal women than in postmenopausal women. Body mass index (BMI) was also associated with current asthma in women, but this association was not significantly affected by adjustment for leptin concentrations.

Conclusions: The results of this large population based study support the hypothesis that leptin is associated with asthma in women. In addition, while BMI also is related to asthma in women, this study does not support the suggestion that leptin contributes significantly to this association.
$\mathrm{S}$ everal studies have shown an association between obesity and asthma, ${ }^{1-18}$ and some have noted that this association may be stronger in women than in men. ${ }^{45} 78$ 19-25 Leptin, the protein product of the obesity $(o b)$ gene, is synthesised and secreted by adipocytes. ${ }^{26}$ Serum leptin levels are strongly correlated with measures of body fat including body mass index (BMI) and skinfold thickness, especially in women. ${ }^{26-29}$ Although its physiological role is incompletely understood, leptin binds to receptors in the hypothalamus and influences the expression of several neuropeptides that regulate energy intake, energy expenditure, and neuroendocrine function. Leptin also regulates immune function and is believed to be pro-inflammatory. ${ }^{30} 31$ Leptin concentrations are increased with oestrogen and progesterone treatment in women, ${ }^{32}$ infectious and inflammatory states, ${ }^{30}{ }^{33}$ and during pregnancy. ${ }^{34}$ Recent studies also suggest that serum leptin concentrations are a predictive factor for asthma in children, especially in boys, independent of BMI. ${ }^{35}$

Despite this evidence, little is known about the association between leptin concentrations and asthma in adults. We hypothesised that high serum leptin concentrations in adults would be associated with asthma and that this association would be stronger in women. We tested this hypothesis in a large, population based, cross sectional study.

\section{METHODS}

\section{Cross sectional study}

The Third National Health and Nutrition Examination Survey (NHANES III) which was carried out from 1988 to 1994 was designed to provide estimates of the health and nutritional status of the civilian non-institutionalised population of the United States. ${ }^{36}$ Participants were selected using a stratified multistage sampling design and were initially interviewed at home; those who accepted an invitation to attend a mobile examination centre were asked to complete additional questionnaires, to undergo a variety of examinations, and to provide a blood specimen.

The study was performed at the Centers for Disease Control and Prevention, Atlanta, GA, USA. This was an anonymous secondary data analysis and no subject identifiers were used. Permission was obtained from the Centers for Disease Control and Prevention, Atlanta, GA, USA and patient consent was obtained for participation and analysis in the original data set.

\section{Leptin concentrations}

Early morning serum leptin concentrations (in $\mu \mathrm{g} / \mathrm{l}$ ) were obtained after an overnight fast of at least 8 hours. Data on the leptin concentrations of 6415 participants aged 20 years or older were available. ${ }^{37}$

The laboratory analysis for serum leptin was performed by Linco Research Inc (St Louis, MO, USA) using a radioimmunoassay with a polyclonal antibody raised in rabbits against highly purified recombinant human leptin. The minimal detectable concentration of this assay was $0.5 \mu \mathrm{g} / \mathrm{l}$ and the limit of linearity was $100 \mu \mathrm{g} / \mathrm{l}$. Intra- and inter-assay coefficients of variation were both less than $5 \%{ }^{37}$

\section{Assessment of asthma}

Asthma was epidemiologically defined, based on two questions:" (1) "Has a doctor ever told you that you had asthma?" and (2) "Do you still have asthma?" Based on the answers to these questions, persons were divided into current asthma (defined as "yes" to both questions) and never asthma (defined as "no" to both questions).

\section{Covariates}

The covariates included age, sex, race/ethnicity, educational status, self-reported smoking status, serum cotinine, BMI, triceps skinfold thickness, physical activity, and atopy status. Smoking status was assessed in two ways - self-report and a measured serum cotinine value. The triceps skinfold thickness was measured in duplicate at the midpoint of the right posterior upper arm using skinfold calipers (Holtain Ltd, Crymmych, UK). In previous studies triceps skinfold

Abbreviations: BMI, body mass index; $C D C$, Centers for Disease Control and Prevention; MET, metabolic equivalent; NHANES III, Third National Health and Nutrition Examination Survey 
thickness has been shown to be a useful field surrogate for measurement of body $\mathrm{fat}^{38}{ }^{39}$ whereas BMI does not distinguish fat weight from non-fat weight. ${ }^{39}$ A measure of physical activity was created by summing the products of the frequency of participation by the metabolic equivalent (MET) levels for each reported activity. Atopy was defined as an affirmative response to the question: "Has a doctor ever told you that you had hay fever?", a case definition from a previous NHANES analysis. ${ }^{40}$

\section{Menopausal status}

Menopause was used as a surrogate marker for a women's reproductive hormonal status, with cycling of oestrogen and progesterone levels being present in actively menstruating women but not in postmenopausal women. Menopause was defined as an age of at least 60 years, or not having a menstrual cycle during the previous 12 months, or having a history of bilateral oophorectomy, or the absence of menses due to chemotherapy or radiation therapy based upon the NHANES III questionnaire.

\section{Statistical analysis}

For statistical analysis, SAS Version 8.2 (Cary, NC, USA) and SUDAAN release 8.0 (Research Triangle Park, NC, USA) were used. SUDAAN was used to take into account the complex sampling design of the survey and provide appropriate standard errors. Sex specific quartiles of concentration of leptin were created. We carried out univariate analyses (to calculate frequency distributions), bivariate analyses (such as $\chi^{2}$ ) and multivariable logistic regression analyses using asthma status (current $v$ never) as the dependent variable. Consistent with our a priori hypothesis, we examined subgroups defined by sex, age and menopausal status, and performed formal tests for interaction. A two sided $\mathrm{p}$ value of $<0.05$ was considered statistically significant.

\section{RESULTS}

A total of 5876 subjects participated in the study after exclusion of those who were either pregnant or had missing values for covariates. All were at least 20 years old, had attended the NHANES III morning mobile examination centre session, and had fasted for at least 8 hours before blood was drawn to measure their leptin concentrations. Of these participants, 290 (4.9\%) currently had asthma and 5586 (95.1\%) had never had asthma. The mean serum leptin concentration was $11.3 \mu \mathrm{g} / \mathrm{l}$ (range 0.5-192.5, median 7.7). The Pearson correlation coefficient between the $\log$ transformed concentration of leptin and triceps skinfold thickness (0.81) was higher than that for BMI (0.57).

Table 1 shows the characteristics of the study participants according to asthma status. Mean BMI and triceps skinfold thickness were higher in those who had current asthma than in those who had never had asthma. In order to understand these findings better the analyses were repeated stratified by sex.

In men the mean BMI in those who had current asthma $\left(27.6 \mathrm{~kg} / \mathrm{m}^{2}\right)$ was not significantly different from those who had never had asthma $\left(26.6 \mathrm{~kg} / \mathrm{m}^{2}, \mathrm{p}=0.23\right)$. The mean triceps skinfold thickness in men with current asthma $(13.3 \mathrm{~mm})$ was also not significantly different from those who had never had asthma $(13.3 \mathrm{~mm}, \mathrm{p}=0.95)$.

On the other hand, in women the mean BMI in those who had current asthma $\left(27.9 \mathrm{~kg} / \mathrm{m}^{2}\right)$ was significantly higher than in those who had never had asthma $\left(26.2 \mathrm{~kg} / \mathrm{m}^{2}\right.$, $\mathrm{p}=0.04)$, but the mean triceps skinfold thickness in those who had current asthma $(24.7 \mathrm{~mm})$ was not significantly different from those who had never had asthma $(23.9 \mathrm{~mm}$, $\mathrm{p}=0.46$ ). This unadjusted analysis shows that BMI, but not triceps skinfold thickness, was associated with current asthma in women. This association between BMI and current asthma in women persisted after adjustment in a multivariable logistic regression analysis for age, sex, race/ ethnicity, educational status, smoking status, concentration of cotinine, physical activity, and atopy (table 2, model 1). Additional adjustment for serum leptin concentrations in this model did not significantly affect the association (table 2, model 2).

Table 1 also shows that mean unadjusted leptin concentrations were higher in participants who had current asthma than in those who had never had asthma. Similarly, the geometric mean (SE) concentrations of leptin were higher in participants who had current asthma $(9.2(0.6) \mu \mathrm{g} / \mathrm{l})$ than in those who had never had asthma $(7.6(0.2) \mu \mathrm{g} / \mathrm{l}, \mathrm{p}=0.02)$.

Adults with the highest quartile of leptin concentrations had an odds ratio (OR) of 1.56 (95\% CI 0.96 to 2.53) for current asthma after adjustment in a multivariable logistic regression analysis for age, sex, race/ethnicity, educational status, smoking status, concentration of cotinine, physical activity, and atopy (table 3, model 1). This association was stronger in women (OR 1.85) than in men (OR 1.27). In women, adjustment for triceps skinfold thickness strengthened the association between serum leptin concentrations and asthma (table 3, model 2) while adjustment for BMI weakened this association (table 3, model 3).

Table 1 Selected characteristics according to asthma status of 5876 study participants aged $\geqslant 20$ years (NHANES III, 1988-1994)

\begin{tabular}{|c|c|c|c|}
\hline \multirow[b]{3}{*}{ Characteristic } & \multicolumn{2}{|l|}{ Asthma status } & \multirow[b]{3}{*}{$p$ value } \\
\hline & \multirow{2}{*}{$\begin{array}{l}\text { Current }(n=290) \\
\text { Mean or \% (SE) }\end{array}$} & \multirow{2}{*}{$\begin{array}{l}\text { Never }(n=5586) \\
\text { Mean or } \%(S E)\end{array}$} & \\
\hline & & & \\
\hline Age (years) & $43.6(1.2)$ & $44.4(0.7)$ & 0.61 \\
\hline Male $(\%)$ & $39.9(4.2)$ & $48.5(1.0)$ & 0.07 \\
\hline White (\%) & $79.7(3.5)$ & $77.0(1.6)$ & 0.44 \\
\hline Education (years) & $12.3(0.2)$ & $12.4(0.1)$ & 0.53 \\
\hline Current smoker (\%) & $34.1(3.6)$ & $27.2(1.1)$ & 0.09 \\
\hline Serum cotinine $(\mathrm{ng} / \mathrm{ml})$ & $78.6(10.3)$ & $73.5(2.8)$ & 0.62 \\
\hline Body mass index $\left(\mathrm{kg} / \mathrm{m}^{2}\right)$ & $27.8(0.6)$ & $26.4(0.2)$ & 0.03 \\
\hline Triceps skinfold thickness (mm) & $20.2(0.7)$ & $18.7(0.2)$ & 0.04 \\
\hline Physical activity (MET frequency) & $110.0(16.1)$ & $112.2(4.4)$ & 0.89 \\
\hline History of diabetes (\%) & $5.7(1.6)$ & $3.7(0.3)$ & 0.23 \\
\hline Presence of domestic pets (\%) & $49.9(3.8)$ & $41.5(1.3)$ & 0.04 \\
\hline History of atopy (\%) & $40.0(4.2)$ & $9.9(0.7)$ & $<0.01$ \\
\hline Leptin concentration ( $\mu \mathrm{g} / \mathrm{l}$, unadjusted) & $13.7(0.9)$ & $11.1(0.3)$ & $<0.01$ \\
\hline
\end{tabular}


Table 2 Association between anthropometric measures of obesity and asthma in study participants aged $\geqslant 20$ years stratified by sex (NHANES III, 1988-1994)*

\begin{tabular}{|c|c|c|c|c|c|c|c|c|c|}
\hline & \multicolumn{3}{|l|}{ Total } & \multicolumn{3}{|l|}{ Men } & \multicolumn{3}{|c|}{ Women } \\
\hline & $\mathbf{n}$ & $\begin{array}{l}\text { Regression } \\
\text { coefficient (SE) }\end{array}$ & $\begin{array}{l}p \text { value } \\
\text { Wald } \chi^{2}\end{array}$ & $\mathbf{n}$ & $\begin{array}{l}\text { Regression } \\
\text { coefficient (SE) }\end{array}$ & $\begin{array}{l}\text { p value } \\
\text { Wald } \chi^{2}\end{array}$ & $\mathbf{n}$ & $\begin{array}{l}\text { Regression } \\
\text { coefficient (SE) }\end{array}$ & $\begin{array}{l}\text { p value } \\
\text { Wald } \chi^{2}\end{array}$ \\
\hline \multicolumn{10}{|c|}{ Model 1 (not adjusted for concentration of leptin) } \\
\hline Triceps skinfold thickness (mm) & 5876 & $0.01(0.01)$ & 0.67 & 2753 & $0.01(0.03)$ & 0.90 & 3123 & $0.01(0.01)$ & 0.70 \\
\hline Body mass index $\left(\mathrm{kg} / \mathrm{m}^{2}\right)$ & 5871 & $0.04(0.02)$ & 0.02 & 2753 & $0.03(0.03)$ & 0.36 & 3118 & $0.05(0.02)$ & $<0.01$ \\
\hline \multicolumn{10}{|c|}{ Model 2 (adjusted for concentration of leptin) } \\
\hline Triceps skinfold thickness (mm) & 5876 & $-0.02(0.01)$ & 0.14 & 2753 & $-0.01(0.03)$ & 0.75 & 3123 & $-0.03(0.02)$ & 0.05 \\
\hline Body mass index $\left(\mathrm{kg} / \mathrm{m}^{2}\right)$ & 5871 & $0.04(0.02)$ & 0.03 & 2753 & $0.04(0.03)$ & 0.28 & 3118 & $0.04(0.02)$ & 0.07 \\
\hline
\end{tabular}

*Models adjusted for age, sex (except sex-specific models), race/ethnicity, educational status, smoking status, cotinine concentration, physical activity, and atopy.

When stratified by age over or under 50 years, the association between concentrations of leptin and current asthma was stronger among women aged 20-49 years (table 4). Because these results suggested that the association might have differed by menopausal status, we also calculated odds ratios for premenopausal and postmenopausal women (table 5). The association between concentrations of leptin and current asthma was stronger in premenopausal women than in postmenopausal women.

Although statistical power was limited, formal tests of interaction were performed to evaluate if sex, age category, or menopausal status changed the association between concentrations of leptin and asthma. The interaction between sex and concentrations of leptin on asthma was not statistically significant whether concentrations of leptin were modelled as quartiles ( $\mathrm{p}\left(\right.$ Wald $\left.\chi^{2}\right)=0.48$ ) or as a continuous variable $\left(\mathrm{p}\left(\right.\right.$ Wald $\left.\chi^{2}\right)=0.37$ ). The interaction between age category and concentrations of leptin on asthma was also not statistically significant when women and men were analysed separately, whether concentrations of leptin were modelled as quartiles ( $p$ (Wald $\left.\chi^{2}\right)=0.74$ for women and 0.12 for men) or as a continuous variable ( $p$ (Wald $\chi^{2}$ ) $=0.36$ for women and 0.86 for men). The interaction between menopausal status and concentrations of leptin on asthma was also not statistically significant whether concentrations of leptin were modelled as quartiles ( $\mathrm{p}\left(\right.$ Wald $\left.\chi^{2}\right)=0.39$ ) or as a continuous variable $\left(\mathrm{p}\left(\right.\right.$ Wald $\left.\left.\chi^{2}\right)=0.46\right)$.

\section{DISCUSSION}

This study suggests that higher serum leptin concentrations are associated with current asthma in adults and that the relationship may be stronger in women than in men. This study also demonstrates three interesting facets of this relationship. Firstly, the association between concentrations of leptin and current asthma appeared stronger in premenopausal than in postmenopausal women. Secondly, adjusting for the two commonly used anthropometric measures of obesity (BMI and triceps skinfold thickness) yielded different results. BMI may confound the association between leptin and asthma, making the association appear larger than may be actually true. On the other hand, adjusting for triceps skinfold thickness does not explain the association of leptin with asthma either, which persists and becomes greater after adjusting for skinfold thickness. The reason for this difference is unclear. Finally, while BMI itself was associated with current asthma in women, this association was not much affected by adjustment for serum leptin concentrations. This suggests that the effect of BMI on asthma is not mediated by the leptin pathway alone and probably involves other mechanistic pathways.

Table 3 Association between serum leptin concentrations and asthma in study participants aged $\geqslant 20$ years stratified by sex (NHANES III, 1988-1994)

\begin{tabular}{|c|c|c|c|c|c|c|}
\hline \multirow[b]{2}{*}{ Leptin quartiles* } & \multicolumn{2}{|l|}{ Total $(n=5876)$} & \multicolumn{2}{|l|}{ Men $(n=2753)$} & \multicolumn{2}{|l|}{ Women $(n=3123)$} \\
\hline & OR $(95 \% \mathrm{Cl})$ & $\begin{array}{l}\text { p value } \\
\text { Wald } \chi^{2}\end{array}$ & OR $(95 \% \mathrm{Cl})$ & $\begin{array}{l}\text { p value } \\
\text { Wald } \chi^{2}\end{array}$ & OR $(95 \% \mathrm{Cl})$ & $\begin{array}{l}\text { p value } \\
\text { Wald } \chi^{2}\end{array}$ \\
\hline \multicolumn{7}{|l|}{ Model $1 \dagger$} \\
\hline Quartile 1 (reference) & 1.00 & 0.06 & 1.00 & 0.20 & 1.00 & 0.08 \\
\hline Quartile 2 & 1.13 (0.69 to 1.86$)$ & & 1.13 (0.55 to 2.33 ) & & $1.11(0.44$ to 2.82$)$ & \\
\hline Quartile 3 & $0.77(0.45$ to 1.30$)$ & & $0.57(0.29$ to 1.15$)$ & & $1.00(0.48$ to 2.09$)$ & \\
\hline Quartile 4 & $1.56(0.96$ to 2.53$)$ & & $1.27(0.50$ to 3.20$)$ & & 1.85 (1.01 to 3.39$)$ & \\
\hline \multicolumn{7}{|l|}{ Model 2‡ } \\
\hline Quartile 1 (reference) & 1.00 & 0.14 & 1.00 & 0.75 & 1.00 & 0.05 \\
\hline Quartile 2 & 1.21 (0.72 to 2.03 ) & & $1.17(0.53$ to 2.59$)$ & & 1.29 (0.48 to 3.44$)$ & \\
\hline Quartile 3 & $0.89(0.50$ to 1.56$)$ & & $0.61(0.27$ to 1.34$)$ & & $1.42(0.60$ to 3.35$)$ & \\
\hline Quartile 4 & $1.99(1.12$ to 3.51$)$ & & $1.43(0.46$ to 4.44$)$ & & 3.19 (1.33 to 7.65$)$ & \\
\hline \multicolumn{7}{|l|}{ Model 3§ } \\
\hline Quartile 1 (reference) & 1.00 & 0.22 & 1.00 & 0.16 & 1.00 & 0.80 \\
\hline Quartile 2 & 1.05 (0.63 to 1.73 ) & & $1.04(0.48$ to 2.25$)$ & & $1.03(0.39$ to 2.69$)$ & \\
\hline Quartile 3 & $0.64(0.40$ to 1.01$)$ & & $0.49(0.24$ to 1.00$)$ & & $0.82(0.40$ to 1.67$)$ & \\
\hline Quartile 4 & 1.05 (0.59 to 1.87 ) & & 0.90 (0.33 to 2.44$)$ & & 1.21 (0.52 to 2.82 ) & \\
\hline
\end{tabular}

$\mathrm{OR}$, odds ratio; $\mathrm{Cl}$, confidence interval.

*For men, quartile 1 is $\leqslant 2.6$, quartile 2 is $>2.6-\leqslant 4.4$, quartile 3 is $>4.4-\leqslant 7.3$, and quartile 4 is $>7.3 \mu \mathrm{g} / \mathrm{l}$. For women, quartile 1 is $\leqslant 7.7$, quartile 2 is $>7.7-$ $\leqslant 13.2$, quartile 3 is $>13.2-\leqslant 21.9$, and quartile 4 is $>21.9 \mu \mathrm{g} / \mathrm{l}$.

†Model 1, adjusted for age, sex (except sex-specific models), race/ethnicity, educational status, smoking status, cotinine concentration, physical activity, and atopy.

$\ddagger$ Model 2, adjusted for variables in model 1 plus triceps skinfold thickness.

§Model 3, adjusted for variables in model 1 plus body mass index. Sample sizes for model 3 are 5871 for all participants, 2753 for men, and 3118 for women. 
Table 4 Association between serum leptin concentration and asthma in study participants stratified by age (NHANES III, 1988-1994)

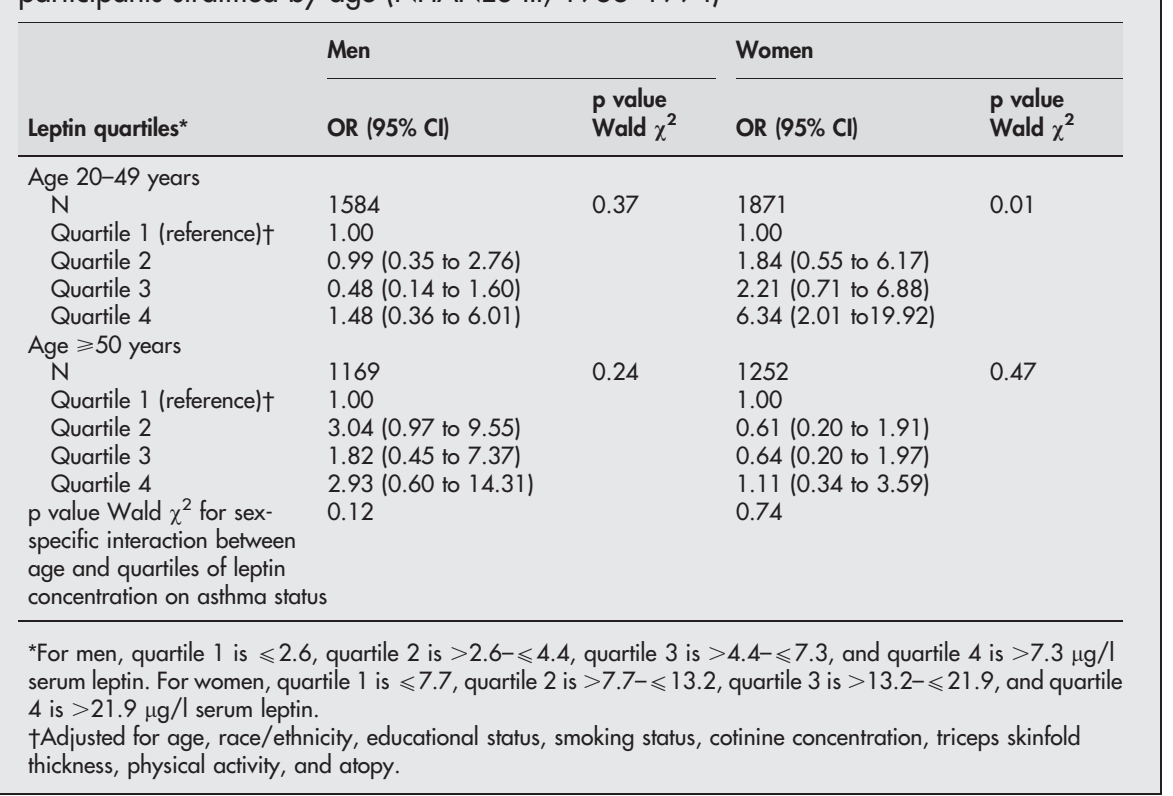

The effect of leptin on lung development and physiology is poorly understood, even though leptin receptors are present in high concentrations in acini of fetal and adult animal lungs. ${ }^{41}$ Leptin is believed to play a role in the intrauterine, neonatal, and postnatal development of murine lung. ${ }^{42}$ In addition, some data suggest that leptin concentrations are increased acutely during inflammation ${ }^{30} 33$ and, in turn, promote inflammation. ${ }^{43-45}$ Support for this comes from experiments showing a prompt dose dependent increase in serum leptin levels and leptin mRNA expression in the adipose tissue of mice following the administration of proinflammatory cytokines such as tumour necrosis factor $\alpha$ (TNF- $\alpha$ ) and interleukin (IL) $-1,{ }^{30}$ as well as demonstration of increased serum TNF- $\alpha$, IL- 6 and IL- 12 levels and increased phagocytosis by macrophages on exogenous administration of leptin. ${ }^{45}$ In wild type mice, administration of exogenous leptin augments ozone induced airway inflammation. ${ }^{43}$ In humans, enhanced concentrations of leptin are related to soluble TNF receptor (sTNF-R) 55, a marker of proinflammatory status in patients with chronic obstructive pulmonary disease. ${ }^{31}$ Guler et $a l^{35}$ found that the median serum leptin concentrations of children (especially boys) were significantly higher in those with asthma than in healthy controls $(3.53 \vee 2.26 \mathrm{ng} / \mathrm{ml}, \mathrm{p}=0.01)$ even though there was no difference in BMI levels. In a study involving children born with very low birth weight who subsequently became overweight, Mai et $a l^{46}$ showed that current asthmatics had median leptin concentrations twice as high as children without current asthma $(30.8 \vee v \quad 14.3 \mathrm{ng} / \mathrm{ml}$, $\mathrm{p}=0.14$ ), but this was not the case in non-overweight children. Taken together, prior studies suggest that leptin may potentially play an important role in the pathophysiology of asthma.

Serum leptin concentrations are also related to obesity. ${ }^{26} 2947$ For equivalent BMI, leptin concentrations are higher in women than in men. ${ }^{28}{ }^{29}$ In addition, obesity is associated with increased concentrations of acute phase proteins, suggesting a pro-inflammatory state. ${ }^{48-50}$ In recent years obesity has been identified as a risk factor for asthma. ${ }^{1-18}$ A prospective study suggested that an increase in weight leads to incident cases of asthma, independent of physical activity. ${ }^{5}$ It is believed by some that a decrease in physical activity, particularly among the obese, may also play a role in the increased prevalence and severity of asthma. ${ }^{51}{ }^{52}$ While the causal pathway remains unknown, the explanations advanced for the association between obesity and asthma include mechanical effects such as lack of tidal stretch leading to latching of airway smooth muscle, immunological effects of

Table 5 Association between serum leptin concentration and asthma in women aged $\geqslant 20$ years according to menopausal status (NHANES III, 1988-1994)

\begin{tabular}{|c|c|c|c|c|}
\hline \multirow[b]{2}{*}{ Leptin quartiles* } & \multicolumn{2}{|c|}{ Premenopausal $(n=1701)$} & \multicolumn{2}{|c|}{ Postmenopausal ( $n=1385$ ) } \\
\hline & OR $(95 \% \mathrm{Cl})$ & $\begin{array}{l}\text { p value } \\
\text { Wald } \chi^{2}\end{array}$ & OR $(95 \% \mathrm{Cl})$ & $\begin{array}{l}\text { p value } \\
\text { Wald } \chi^{2}\end{array}$ \\
\hline $\begin{array}{l}\text { Quartile } 1 \text { (reference)† } \\
\text { Quartile } 2 \\
\text { Quartile } 3 \\
\text { Quartile } 4\end{array}$ & $\begin{array}{l}1.00 \\
1.80(0.51 \text { to } 6.35) \\
1.69(0.50 \text { to } 5.63) \\
3.56(1.11 \text { to } 11.36)\end{array}$ & 0.048 & $\begin{array}{l}1.00 \\
0.60(0.19 \text { to } 1.90) \\
1.06(0.40 \text { to } 2.76) \\
2.16(0.60 \text { to } 7.76)\end{array}$ & 0.114 \\
\hline
\end{tabular}

*For women, quartile 1 is $\leqslant 7.7$, quartile 2 is $>7.7-\leqslant 13.2$, quartile 3 is $>13.2-\leqslant 21.9$, and quartile 4 is $>21.9 \mu \mathrm{g} / \mathrm{l}$ serum leptin.

†Adjusted for age, race/ethnicity, educational status, smoking status, cotinine concentration, triceps skinfold thickness, physical activity, and atopy.

The interaction between menopausal status and concentrations of serum leptin modelled in quartiles on asthma status was not significant ( $p\left(\right.$ Wald $\left.\chi^{2}\right)=0.39$ ). 
pro-inflammatory cytokines, genetic, hormonal and environmental effects such as change in dietary factors and increased exposure to indoor allergens. ${ }^{53} 54$

Some investigators have noted that the association between obesity and asthma may be stronger in women than in men, suggesting that reproductive hormones might be involved in the causal pathway. ${ }^{47819-25}$ In addition, Castro-Rodriguez et al found this association to be stronger in girls whose puberty started before the age of 11 years than in girls whose puberty started later. Barr et al ${ }^{55}$ showed that exogenous hormone replacement therapy in adult postmenopausal women was associated with an increased relative risk for asthma, with a positive dose-response between the daily dose of conjugated oestrogens and the risk of asthma. Similarly, administration of exogenous reproductive hormones to women has also been noted to increase serum leptin concentrations further. ${ }^{32}$ These observations have led some to conclude that leptin may be important in explaining the link between obesity and asthma, particularly in women.

Our study does not support the assertion that leptin plays a dominant role in the association between obesity and asthma in women, but it does support the conclusion that leptin itself may play a part in asthma in women. This would be consistent with data obtained from previous animal and human studies. ${ }^{31354346}$ Further relationships between asthma, leptin, and female reproductive hormones cannot be adequately addressed in this study because of the cross sectional design and inadequate sample size.

The study has some additional limitations. The definition of asthma was a self-reported doctor diagnosis of asthma, and this may result in some misclassification bias. Serum reproductive hormone concentrations were not measured nor were the leptin concentrations measured in relation to the day of the menstrual cycle in premenopausal women. Finally, in order to confirm definitively that leptin has a different effect on asthma status in various groups, a statistically significant interaction is required. It is not sufficient to observe a statistically significant relationship in one group and not in the other. ${ }^{56}$ This exploratory analysis lacks the power to detect a statistically significant interaction and further work in larger cohorts is warranted.

In summary, using nationally representative data, this study has shown that higher serum leptin concentrations are associated with current asthma in women and that this association may be stronger in premenopausal women. In addition, while BMI is also associated with current asthma in women, this study does not confirm that leptin contributes significantly to this association. Future studies will need to confirm and expand on these observations to improve our understanding of the pathogenesis of asthma.

\section{ACKNOWLEDGEMENTS}

The authors thank William S Beckett, MD, MPH, University of Rochester School of Medicine and Dentistry for his careful critique of the manuscript.

\section{Authors' affiliations \\ A Sood, Division of Pulmonary and Critical Care Medicine, Southern Illinois University School of Medicine, Springfield, IL, USA \\ E S Ford, Centers for Disease Control and Prevention, Atlanta, GA, USA C A CamargoJr, Department of Emergency Medicine, Massachusetts General Hospital, Harvard Medical School, Boston, MA, USA}

No sponsorship was obtained for this study. There is no author involvement with organisation(s) with financial interest in the subject matter. Dr Carlos Camargo is supported in part by grant Al-52338 from the National Institutes of Health, Bethesda, MD, USA.

Competing interests: none.

\section{REFERENCES}

1 Chinn S. Obesity and asthma: evidence for and against a causal relation. J Asthma 2003;40:1-16.

2 Chinn S, Jarvis D, Burney P. Relation of bronchial responsiveness to body mass index in the ECRHS. European Community Respiratory Health Survey. Thorax 2002;57:1028-33.

3 Litonjua AA, Sparrow D, Celedon JC, et al. Association of body mass index with the development of methacholine airway hyperresponsiveness in men: the Normative Aging Study. Thorax 2002;57:581-5.

4 Chen $Y$, Dales $R$, Tang $M$, et al. Obesity may increase the incidence of asthma in women but not in men: longitudinal observations from the Canadian National Population Health Surveys. Am J Epidemiol 2002;155:191-7.

5 Beckett WS, Jacobs DR Jr, Yu X, et al. Asthma is associated with weight gain in females but not males, independent of physical activity. Am J Respir Crit Care Med 2001;164:2045-50.

6 Celedon JC, Palmer $\amalg$, Litonjua AA, et al. Body mass index and asthma in adults in families of subjects with asthma in Anqing, China. Am J Respir Crit Care Med 2001;164:1835-40.

7 Castro-Rodriguez JA, Holberg CJ, Morgan WJ, et al. Increased incidence of asthmalike symptoms in girls who become overweight or obese during the school years. Am J Respir Crit Care Med 2001;163:1344-9.

8 Figueroa-Munoz JI, Chinn S, Rona RJ. Association between obesity and asthma in 4-11 year old children in the UK. Thorax 2001;56:133-7.

9 Camargo CA Jr, Weiss ST, Zhang S, et al. Prospective study of body mass index, weight change, and risk of adult- onset asthma in women. Arch Intern Med 1999; 159:2582-8.

10 Guerra S, Sherrill DL, Bobadilla A, et al. The relation of body mass index to asthma, chronic bronchitis, and emphysema. Chest 2002;122:1256-63.

11 Huovinen E, Kaprio J, Koskenvuo M. Factors associated to lifestyle and risk of adult onset asthma. Respir Med 2003;97:273-80.

12 Ford ES, Mannino DM, Redd SC, et al. Body mass index and asthma incidence: Findings from National Health and Nutrition Examination Survey $\mid$ epidemiologic follow-up study. Am J Resp Crit Care Med 2003;165:A442.

13 Nystad W, Meyer HE, Nafstad P, et al. Body mass index in relation to adult asthma among 135,000 Norwegian men and women. Am J Epidemiol 2004; 160:969-76.

14 Stanley AH, Demissie K, Rhoads GG. Asthma development with obesity exposure: observations from the cohort of the National Health and Nutrition Evaluation Survey Epidemiologic Follow-up Study (NHEFS). J Asthma 2005:42:97-9.

15 Gilliland FD, Berhane K, Islam T. Obesity and the risk of newly diagnosed asthma in school-age children. Am J Epidemiol 2003;158:406-15.

16 Chinn S, Rona RJ. Can the increase in body mass index explain the rising trend in asthma in children? Thorax 2001;56:845-50.

17 Gold DR, Damokosh Al, Dockery DW, et al. Body-mass index as a predictor of incident asthma in a prospective cohort of children. Pediatr Pulmonol 2003;36:514-21.

18 Guerra S, Wright AL, Morgan WJ, et al. Persistence of asthma symptoms during adolescence: role of obesity and age at the onset of puberty. Am J Respir Crit Care Med 2004;170:78-85.

19 Del-Rio-Navarro BE, Fanghanel G, Berber A, et al. The relationship between asthma symptoms and anthropometric markers of overweight in a Hispanic population. J Invest Allergol Clin Immunol 2003;13:1 18-23.

20 Seidell JC, de Groot LC, van Sonsbeek JL, et al. Associations of moderate and severe overweight with self-reported illness and medical care in Dutch adults. Am J Public Health 1986;76:264-9.

21 von Kries R, Hermann M, Grunert VP, et al. Is obesity a risk factor for childhood asthma? Allergy 2001;56:318-22.

22 Chen Y, Dales R, Krewski D, et al. Increased effects of smoking and obesity on asthma among female Canadians: the National Population Health Survey, 1994-1995. Am J Epidemiol 1999;150:255-62.

23 Huang SL, Shiao G, Chou P. Association between body mass index and allergy in teenage girls in Taiwan. Clin Exp Allergy 1999;29:323-9.

24 Hancox RJ, Milne BJ, Poulton R, et al. Sex differences in the relation between body mass index and asthma and atopy in a birth cohort. Am J Respir Crit Care Med 2005;171:440-5.

25 Guerra S, Sherrill DL, Bobadilla A, et al. The relation of body mass index to asthma, chronic bronchitis, and emphysema. Chest 2002;122:1256-63.

26 Considine RV, Sinha MK, Heiman ML, et al. Serum immunoreactive-leptin concentrations in normal-weight and obese humans. N Engl J Med 1996;334:292-5.

27 Friedman JM. Leptin, leptin receptors, and the control of body weight. Nutr $\operatorname{Rev} 1998 ; 56: s 38-46$, s54-75

28 Rosenbaum M, Nicolson M, Hirsch J, et al. Effects of gender, body composition, and menopause on plasma concentrations of leptin. J Clin Endocrinol Metab 1996:81:3424-7.

29 Ruhl CE, Everhart JE. Leptin concentrations in the United States: relations with demographic and anthropometric measures. Am J Clin Nutr $2001 ; 74: 295-301$

30 Sarraf $\mathbf{P}$, Frederich RC, Turner EM, et al. Multiple cytokines and acute inflammation raise mouse leptin levels: potential role in inflammatory anorexia. J Exp Med 1997; 185:171-5.

31 Schols AM, Creutzberg EC, Buurman WA, et al. Plasma leptin is related to proinflammatory status and dietary intake in patients with chronic obstructive pulmonary disease. Am J Respir Crit Care Med 1999;160:1220-6.

32 Messinis IE, Papageorgiou I, Milingos S, et al. Oestradiol plus progesterone treatment increases serum leptin concentrations in normal women. Hum Reprod 2001;16:1827-32.

33 Faggioni R, Fantuzzi G, Fuller J, et al. IL-1 beta mediates leptin induction during inflammation. Am J Physiol 1998;274:R204-8. 
34 Holness MJ, Munns MJ, Sugden MC. Current concepts concerning the role of leptin in reproductive function. Mol Cell Endocrinol 1999;157:11-20.

35 Guler N, Kirerleri E, Ones U, et al. Leptin: does it have any role in childhood asthma? J Allergy Clin Immunol 2004;1 14:254-9.

36 US Department of Health and Human Services. National Center for Health Statistics. Third National Health and Nutrition Examination Survey, 19881994, NHANES III Laboratory Data File. Public Use Data File Documentation Number 76200. Hyattsville, MD: Centers for Disease Control and Prevention and National Center for Health Statistics, 1996.

37 US Department of Health and Human Services. National Center for Health Statistics. Third National Health and Nutrition Examination Survey, 19881994, NHANES III Serum Leptin Data File (Series 11, No. 12A). Hyattsville, MD: Centers for Disease Control and Prevention, 2001

38 Lohman TG, Pollock ML, Slaughter MH, et al. Methodological factors and the prediction of body fat in female athletes. Med Sci Sports Exerc 1984; 16:92-6.

39 Keller C, Thomas KT. Measurement of body fat and fat distribution. J Nurs Meas 1995;3:159-74.

40 Arif AA, Whitehead LW, Delclos GL, et al. Prevalence and risk factors of work related asthma by industry among United States workers: data from the third national health and nutrition examination survey (1988-94). Occup Environ Med 2002;59:505-11.

41 Bergen HT, Cherlet TC, Manuel P, et al. Identification of leptin receptors in lung and isolated fetal type II cells. Am J Respir Cell Mol Biol 2002;27:71-7.

42 Hoggard N, Hunter L, Duncan JS, et al. Leptin and leptin receptor mRNA and protein expression in the murine fetus and placenta. Proc Natl Acad Sci USA 1997;94:1 1073-8.

43 Shore SA, Rivera-Sanchez YM, Schwartzman IM, et al. Responses to ozone are increased in obese mice. J Appl Physiol 2003;95:938-45.

44 Loffreda S, Yang SQ, Lin HZ, et al. Leptin regulates proinflammatory immune responses. Faseb J 1998;12:57-65.
45 Gosset P, Tsicopoulos A, Wallaert B, et al. Tumor necrosis factor alpha and interleukin-6 production by human mononuclear phagocytes from allergic asthmatics after lgE-dependent stimulation. Am Rev Respir Dis 1992;146:768-74.

46 Mai XM, Bottcher MF, Leijon I. Leptin and asthma in overweight children at 12 years of age. Pediatr Allergy Immunol 2004;15:523-30.

47 Shimizu H, Shimomura Y, Hayashi R, et al. Serum leptin concentration is associated with total body fat mass, but not abdominal fat distribution. Int J Obes Relat Metab Disord 1997;21:536-41.

48 van Dielen FM, van't Veer C, Schols AM, et al. Increased leptin concentrations correlate with increased concentrations of inflammatory markers in morbidly obese individuals. Int J Obes Relat Metab Disord 2001;25:1759-66.

49 Visser M, Bouter LM, McQuillan GM, et al. Elevated C-reactive protein levels in overweight and obese adults. JAMA 1999;282:2131-5.

50 Ford ES. Body mass index, diabetes, and C-reactive protein among US adults. Diabetes Care 1999;22:1971-7.

51 Firrincieli V, Keller A, Ehrensberger R, et al. Decreased physical activity among headstart children with a history of wheezing: use of an accelerometer to measure activity. Pediatr Pulmonol 2005;40:57-63.

52 Lucas SR, Platts-Mills TA. Physical activity and exercise in asthma: relevance to etiology and treatment. J Allergy Clin Immunol 2005;1 15:928-34.

53 Ding DJ, Martin JG, Macklem PT. Effects of lung volume on maximal methacholine-induced bronchoconstriction in normal humans. J Appl Physiol 1987;62:1324-30.

54 Sood A. Does obesity weigh heavily on the health of the human airway? J Allergy Clin Immunol 2005;115:921-4.

55 Barr RG, Wentowski CC, Grodstein F, et al. Prospective study of postmenopausal hormone use and newly diagnosed asthma and chronic obstructive pulmonary disease. Arch Intern Med 2004; 164:379-86.

56 Altman DG, Bland JM. Interaction revisited: the difference between two estimates. BMJ 2003;326:219.

\section{LUNG ALERT}

Inhaled cyclosporine may increase survival after lung transplantation

$\Delta$ lacono AT, Johnson BA, Grgurich WF, et al. A randomized trial of inhaled cyclosporine in lung-transplant recipients. N Engl J Med 2006;354:141-50

$\mathrm{n}$ this single centre, randomised, double blind, placebo controlled trial, inhaled cyclosporine $300 \mathrm{mg}$ or placebo was given in addition to conventional immunosuppression for 3 days a week for the first 2 years after lung transplantation. The trial included 58 recipients of a single or bilateral lung transplant. The primary end point was the rate of histological acute rejection, with secondary end points including chronic rejection free survival and mortality.

There was no difference in the primary end point with rates of acute rejection similar in the cyclosporine and placebo groups $(0.44$ (95\% CI 0.31 to 0.62$)$ episodes per patient per year in the cyclosporine group and 0.46 (95\% CI 0.33 to 0.64$)$ per patient per year in the placebo group). Secondary end points did show improvement with inhaled cyclosporine. There were only three deaths in the treatment arm compared with 14 in the placebo group (relative risk of death $0.20,95 \%$ CI 0.06 to $0.70 ; p=0.01$ ), showing that overall survival was improved. Chronic rejection free survival as determined by spirometric and histological analysis also showed improvement. The risk of nephrotoxic effects and opportunistic infection were similar in both groups.

This study shows that, although there was no difference in acute rejection, inhaled cyclosporine improved survival and extended periods of chronic rejection free survival. These results are surprising as previous studies have linked repeated episodes of acute rejection with chronic rejection. The authors propose that, as chronic rejection begins in the airways as bronchiolitis obliterans, inhaled treatment may have a greater effect than in acute rejection where the pathology is mainly vasculitic. Further experience is needed to confirm the magnitude and durability of these results.

A Sykes

Specialist Registrar, Hammersmith Hospital, London, UK; AnneSykes@hhnt.nhs.uk 